\title{
Genetic and Bio-Ecologic Characteristics of Common Pandora Pagellus erythrinus from the Eastern Mediterranean Coast of Turkey for the Ecosystem-Based Fishery Management
}

\author{
Ali Uyan ${ }^{1}$, Cemal Turan ${ }^{1, *}\left(\mathbb{D}\right.$, Mevlut Gurlek ${ }^{1}$, Deniz Yaglioglu ${ }^{2}$ \\ ${ }^{1}$ Iskenderun Technical University, Faculty of Marine Sciences and Technology, Molecular Ecology and Fisheries \\ Genetics Laboratory, 31220 Iskenderun, Hatay, Turkey. \\ ${ }^{2}$ Duzce University, Department of Biology, Duzce, Turkey.
}

\section{Article History}

Received 08 February 2020

Accepted 27 March 2020

First Online 31 March 2020

\section{Corresponding Author \\ Tel.: +90326 6141693 \\ E-mail: cemal.turan@iste.edu.tr}

\section{Keywords}

Pagellus erythrinus

Stock identification

mtDNA sequencing

Growth parameters

Northeastern Mediterranean

\begin{abstract}
Genetic structure and growth characteristics of common pandora Pagellus erythrinus populations collected from the Iskenderun, Mersin and Antalya Bays were revealed through D-loop sequencing of mtDNA and length-weight and age-length relationships. While the highest value of genetic diversity was obtained in the Mersin population (0.0024), the lowest value was in Iskenderun population (0.0006). A total of 9 haplotypes was found and mean haplotype diversity was found 0.7485 . The highest genetic divergence was observed between the Mersin and Iskenderun Bay populations (0.0206), whereas the Iskenderun and Antalya Bay populations had the least genetic divergence (0.0165). BioMorphv3 was used for determining the length-weight and age-length relationships. The length-weight relationships for all individuals of Iskenderun, Mersin and Antalya populations were estimated as $W=0.0693 \times L^{2.3887}$ $(r=0.9456), W=0.0786 \times L^{2.3338}(r=0.9473)$ and $W=0.0693 \times L^{2.3887}(r=0.9542)$, respectively. The von Bertalanffy growth parameters for all individuals of Iskenderun, Mersin and Antalya populations were calculated as $L_{t}=39.22\left[1-e^{0.210(t+0.32)}\right], L_{t}=50.48$ $\left[1-e^{0.120(t+2.76)}\right], L_{t}=38.08\left[1-e^{0.158(t+0.48)}\right]$, respectively.
\end{abstract}

\section{Introduction}

The common pandora Pagellus erythrinus (Linnaeus, 1758) is a commercially important demersal fish species which belongs to Sparidae family, distributed in the coastal waters of the Mediterranean, the western Black Sea and the eastern Atlantic Ocean from Norway to Angola (Whitehead, Bauchot, Hureau, Nielsen \& Tortonese, 1986; Froese \& Pauly, 2019) and lives at depths of 20 to $300 \mathrm{~m}$ on sandy-muddy zones (Santos, Monteiro, \& Erzini, 1995). The common pandora have the feature of protogynous hermaphroditism (Girardin \& Quignard, 1985; Papaconstantinou, Mytilineou, \& Panos, 1988; Livadas, 1989). Females usually turn into males when they are at the ages of two or three and reach a total length of 170$180 \mathrm{~mm}$ (Coelho et al., 2010). Reproduction occurs during late spring and summer, and eggs and larvae are pelagic (Spedicato et al., 2002). The main foods of the common pandora consist of Decapoda, Bivalvia, Polychaeta, Euphausiacea, Teleostei, Mysidacea, and Cephalopoda (Šantić, Paladin, \& Rađa, 2011). It is also known as one of the most promising new candidate species in Mediterranean aquaculture (Micale, Garaffo, Genovese, Spedicato, \& Muglia, 2006). The maximum total length is reported as $60 \mathrm{~cm}$ (Froese \& Pauly, 2019) and weight as $3.2 \mathrm{~kg}$ (IGFA, 2001).

Fisheries pressure on the common pandora has increased further in the last 30 years, especially on the North African coasts of the Mediterranean. (FAO, 2018). This species is also considered as an important fishery resource in the Mediterranean and Atlantic waters (Erzini, Gonçalves, Bentes, Lino, \& Ribeiro, 1998). The signs of the over-exploitation have been reported in the 
existing stocks of the species in various Mediterranean geographical sub-areas (GSAs) (Abella, Colloca, Sartor, \& Mannini, 2010). Despite the increasing of the catch rates, the common pandora is reported as the least worried species in the IUCN Threatened Species Red List (Russell, 2014). In the current conservation legislation for the fisheries in the Mediterranean Sea, the minimum total length limit for this species has been identified as $15 \mathrm{~cm}$ (European Commission, 2006). Common pandora is captured by gills or trammel nets, longline and trawl. The total production amount is 980 tones, which relates to $0.37 \%$ of the quantity of caught sea fish in the Turkish Seas (TURKSTAT, 2016).

Several studies about genetic structure of the common pandora were conducted by Fassatoui, Mdelgi, and Romdhane (2009); Fassatoui, Mdelgi, and Romdhane (2011); Apostolidis, Moutou, Stamatis, and Mamuris, (2009); Fassatoui and Romdhane (2010); Angiulli, Sola, Ardizzone, Fassatoui, and Rossi (2016); Rossi et al. (2019). On the other hand, growth parameters and biological characteristics of the common pandora were investigated in various areas of the Mediterranean such as, the southeast coasts of Spain (Valdes et al., 2004), the Tyrrhenian Sea (Busalacchi, Bottari, Giordano, Profeta, \& Rinelli, 2014), the Adriatic Sea (Šantić et al., 2011), the Cretan shelf (Somarakis \& Machias, 2002), the Ionian Sea (Caragitsou \& Papaconstantinou, 1988), the Libyan coasts (Hashem \& Gassim, 1981), the Algerian coasts (Mahdi, Talet, \& Boutiba, 2018) and the Tunisian coasts (Ben Smida \& Hadhri, 2014; Fassatoui, Hmida, Jenhani, \& Romdhane, 2019). In Turkish marine waters, the population characteristics were studied by Özaydın (1997); Tosunoğlu, Akyol, Metin, Tokaç, and Ünsal (1997); Stergiou and Moutopoulos (2001); Hoşsucu and Çakır (2003); Gökçe, Aydın, and Metin (2007); Metin, illkyaz, Soykan, and Kınacıgil (2011); Gurbet, Akyol, and Yalçın (2012); Akalın, İlhan, and Özaydın (2015); Öztekin, Özekinci, and Daban (2016); Ayyıldız and Altın (2018); Yapıcı and Filiz (2019) in the Aegean Sea; Sangün, Akamca, and Akar (2007); Gökçe, Çekic, and Filiz (2010); Özvarol (2014) in eastern Mediterranean Sea.

The assessment of gen flow levels among populations and population dynamics parameters is vital for management of marine stocks (Palsbøll, Berube, \& Allendorf, 2007). Mitochondrial DNA (mtDNA) is widely used as a marker for population studies due to its compact size, rapid evolution rate, and exclusive maternal inheritance mode (Harrison, 1989). The mtDNA control region is also known as displacement loop (D-loop) region evolves much faster than average due to reduced functional constraints (Brown, 1985).

According to our knowledge, the genetic variations between $P$. erythrinus populations in the marine waters of Turkey was still unknown in detail. Thus, genetic structure of $P$. erythrinus populations from the Iskenderun, Mersin and Antalya Bays were revealed based on mitochondrial D-loop sequence data in this study. In order to contribute to a better knowledge of the population dynamic studies, we investigated growth parameters of the common pandora from Iskenderun, Mersin and Antalya Bays.

\section{Materials and Methods}

\section{Sample Collection}

$P$. erythrinus specimens were sampled by collecting from commercial trawl fishing from three fishing areas of the eastern Mediterranean, comprising the Antalya Bay (ANT), Mersin Bay (MER) and Iskenderun Bay (ISK) between 2017-2019 (Figure 1). 20 common pandora samples were collected from each sites for population genetic analysis. The specimens were delivered to the laboratory and stored in a deepfreeze at $-30^{\circ} \mathrm{C}$ until DNA extraction. In the lengthweight and age-length relationships, overall 958 specimens, of which 346 ISK, 310 MER and 302 ANT populations, were measured for the length- weight relationships.

\section{Genetic Analysis}

The standard phenol: chloroform: isoamyl alcohol procedure (Sambrook, Fritsch, \& Maniatis, 1989) was used to extract DNA from muscle of all fish samples. The mitochondrial D-loop gene was amplified through PCR with universal primers.

\section{F: 5'-ATC ATC GGC CAA ATC GCA TC-3' \\ R: 5'-GAA CTG TAG GGC ATT CTC AC-3'}

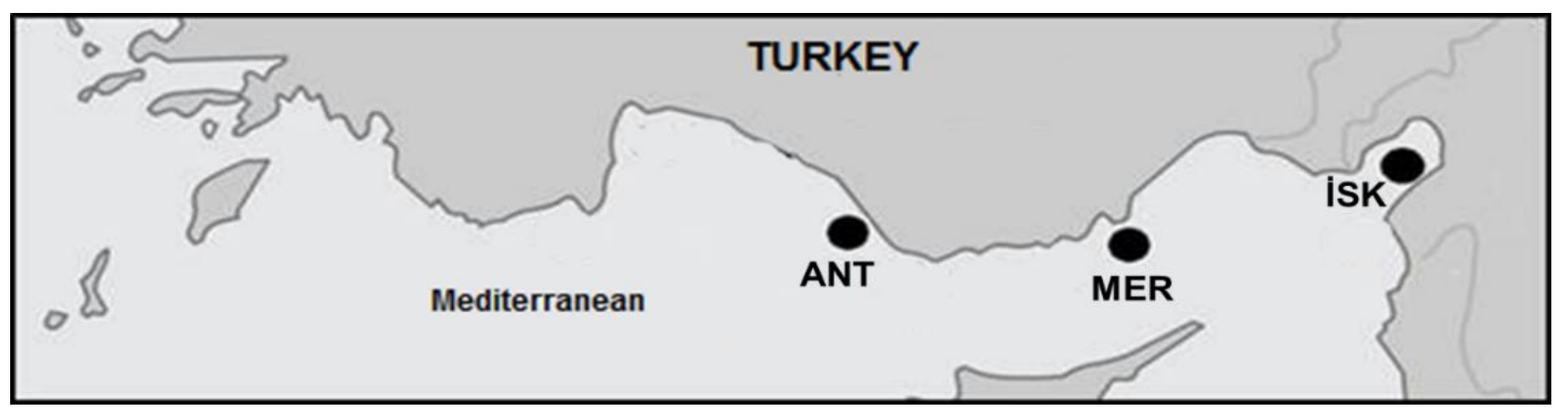

Figure 1. Sampling locations of P. erythrinus: ANT (Antalya Bay); MER (Mersin Bay); ISK (Iskenderun Bay). 
Polymerase chain reactions were at using a reaction volume of $25 \mu \mathrm{l}$ containing 5 units of Taq polymerase (Thermo scientific), $2 \mathrm{mM}$ of each primer, $10 \mathrm{mM}$ dNTPs (Thermo scientific), $25 \mathrm{mM} \mathrm{MgCl} 2$ (Thermo scientific), $10 \mathrm{mM}$ Tris- $\mathrm{HCl} \mathrm{pH} 8.8,50 \mathrm{mM} \mathrm{KCl}$ and $1 \mu$ template DNA ( $10-25 \mathrm{ng}$ ). The amplification was performed with a profile of 1 cycle of denaturation at $94^{\circ} \mathrm{C}$ for $5 \mathrm{~min}$, followed by 40 cycles of strand denaturation at $94^{\circ} \mathrm{C}$ for $1 \mathrm{~min}$, annealing at $50^{\circ} \mathrm{C}$ for 1 min and primer extensions $72^{\circ} \mathrm{C}$ for $1 \mathrm{~min} 30 \mathrm{~s}$, and 1 cycle of final elongation at $72^{\circ} \mathrm{C}$ for $5 \mathrm{~min}$. After PCR amplification, a $3 \mu \mathrm{l}$ sample of each PCR product was controlled in $1.5 \%$ agarose gels.

Finally, sequencing process of the PCR products were carried out in the forward direction with an automated sequencing machine.

\section{Sequence Alignment}

Clustal W (Thompson, Higgins, \& Gibson, 1994) was used to align the partial sequences of D-loop, and BioEdit (Hall, 1999) was used to perform manual final alignment. MEGA 5 (Tamura et al., 2011) was used to analyze mtDNA sequence data and to interpret values of pairwise nucleotide variation and to find out the nucleotide composition of populations individually.

\section{Statistical Analysis}

After sequence alignment, MEGA v5 was used to determine the genetic diversity and sequence divergences, and to construct the phylogenetic tree (Tamura et al., 2011). Genetic diversity was measured within and between populations by the maximum likelihood estimation (Nei, 1987). Jukes-Cantor model (Jukes \& Cantor, 1969) was found as best-fitting model of nucleotide substitution and genetic diversity via ModelTest (Posada \& Crandall, 1998). Neighbor Joining tree (Saitou \& Nei, 1987) was used to demonstrate genetic relationship between populations with consideration of negative branch length. The statistical robustness in the nodes of the resulting tree was determined by 1000 bootstrap replicates. In order to analyze the relevance of the DNA sequence evolution to neutrality, Tajima's D test (Tajima, 1989) was performed.

\section{Estimating of Population Parameters}

The length-weight relationships were separately evaluated for each common pandora populations of all individuals with the formula $W=a \times L^{b}$, where $W$ is total body weight $(\mathrm{g}), L$ is total length $(\mathrm{cm})$, and $a$ and $b$ are coefficients (Ricker, 1973). Growth characteristics was estimated by the von Bertalanffy growth functions (Sparre \& Venema, 1998). The function $L_{t}=L_{\infty}\left[1-\mathrm{e}^{-k(t-t o)}\right]$ was applied to the data where $L_{t}$ is the fish length $(\mathrm{cm})$ at the time $t$ (year), $L_{\infty}$ is the asymptotic length $(\mathrm{cm}), k$ is the growth coefficient (year ${ }^{-1}$ ), and to (year) is the theoretical time at which the length is equal $t_{0}$ zero.

The photographs were taken from all the common pandora samples. Total weight (nearest $0.01 \mathrm{~g}$ ) of all the samples and the age readings as suggested by Holden and Raitt (1974) from all the sagittal otoliths were recorded. BioMorphv3 was used for the age and growth relationship from the images of fish and recorded weight and age data.

\section{Results}

\section{Genetic results}

314 bp partial D-loop gene sequences were obtained after alignment. The average nucleotide composition of thymine $(T)$, cytosine $(C)$, adenine $(A)$, and guanine $(\mathrm{G})$ were examined as $26.5 \%, 26.7 \%, 26.0 \%$ and $20.8 \%$, respectively. The D-loop dataset contained 13 variable sites, 10 of which were parsimony informative. DNA sequence analysis with the D-loop gene revealed 9 different haplotypes (Table 1). Mean haplotype diversity between populations was found to be 0.7485 .

The phylogenetic relationships among the identified haplotypes were constructed and consequently a star-like shape, symbolized by a large number of unmatched haplotypes, often related to the central and plenty of haplotypes was obtained with Minimum Spanning Tree (Hap1) (Figure 2).

Table 1. Distribution and frequency of D-loop haplotypes of $P$. erythrinus populations.

\begin{tabular}{lccc}
\hline Haplotypes & ISK & MER & ANT \\
\hline Hap_1 & - & - & 1 \\
Hap_2 & 5 & 6 & 19 \\
Hap_3 & 15 & - & - \\
Hap_4 & - & 1 & - \\
Hap_5 & - & 1 & - \\
Hap_6 & - & 5 & - \\
Hap_7 & - & 1 & - \\
Hap_8 & - & 5 & - \\
Hap_9 & - & 1 & - \\
\hline Total & 20 & 20 & 20 \\
\hline
\end{tabular}


Intra-population genetic diversity and interpopulation total genetic distance values are presented in Table 2.

Genetic diversity was determined as the lowest in the ISK samples, whereas the highest was in the MER samples.

Inter-population genetic diversity was 0.0127 . Mean genetic divergence among populations was 0.0183. For inter-population comparison, the ISK and ANT populations showed the lowest genetic differentiation (0.0165), while the ISK and MER populations was the highest (0.0206) (Table 2). Pairwise comparisons of genetic distance indicated that all the three populations statistically differed from each other $(P<0.05)$.

In NJ tree analysis, the MER populations was differ $(P<0.05)$ from the other populations, whereas the ISK and ANT were clustered together (Figure 3).

Tajima's D (Tajima, 1989) for the $P$. erythrinus populations was found to 1.3631 , indicating that the observed heterozygosity is higher than that expected (Table 3).

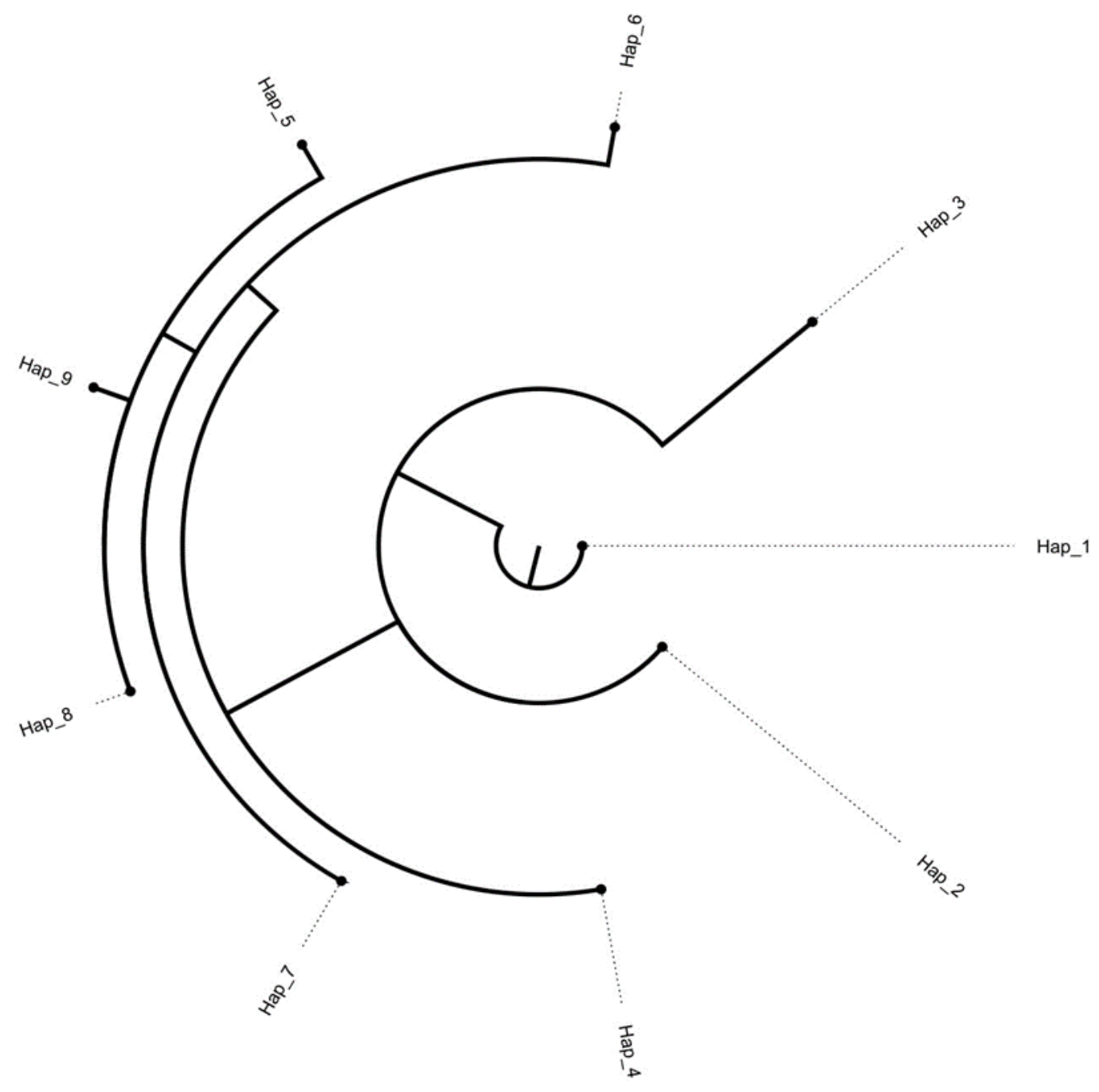

2.0

Figure 2. Minimum Spanning Tree of the mtDNA D-loop haplotypes of $P$. erythrinus reconstructed with neighbor joining method.

Table 2. Pairwise genetic distance between populations (below the diagonal). Bold numbers in Triangular line represent mean genetic diversity within populations. ${ }^{*}, \mathrm{P}<0.05$.

\begin{tabular}{lccc}
\hline Populations & ISK & MER & ANT \\
\hline ISK & 0.0006 & & \\
MER & $0.0206^{*}$ & 0.0024 & 0.0008 \\
ANT & $0.0165^{*}$ & $0.0178^{*}$ & \\
\hline
\end{tabular}




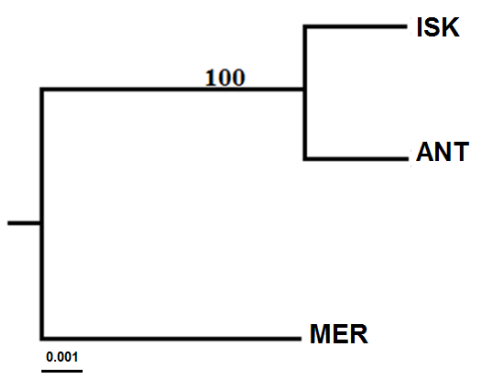

Figure 3. Mitochondrial DNA D-loop neighbor joining tree of $P$. erythrinus samples.

Table 3. Neutrality tests and the estimated parameters of mismatch distribution for populations of $P$. erythrinus from Turkish waters.

\begin{tabular}{lccccc}
\hline $\mathrm{m}$ & $\mathrm{S}$ & $\mathrm{P}_{\mathrm{s}}$ & $\Theta$ & $\pi$ & $\mathrm{D}$ \\
\hline 75 & 13 & 0.041401 & 0.008517 & 0.012632 & 1.363177 \\
\hline $\mathrm{m}$, number & &
\end{tabular}

\section{Length-Weight Relationship}

The length-weight relationships were separately evaluated for each populations of all individuals, and were given in Figure 4 . The exponent $b$ demonstrated a negative allometric growth. The length-weight relationships were calculated for ISK, MER and ANT populations of all individuals as $W=0.1219 \times L^{2.1543}$ $(r=0.9456), W=0.0786 \times L^{2.3338}(r=0.9473)$ and $W=0.0693$ $x L^{2.3887}(r=0.9542)$, respectively.

\section{Age-Total Length Relationship}

The estimated von Bertalanffy growth parameters of all individuals of common pandora $L_{\infty}=39.22 \mathrm{~cm}$, $K=0.210$ and $t_{o}=0.32$ for ISK samples; $L_{\infty}=50.48 \mathrm{~cm}$, $K=0.120$ and $t_{o}=2.76$ for MER samples and $L_{\infty}=38.08 \mathrm{~cm}$, $K=0.158$ and $t_{o}=0.48$ for ANT samples.

\section{Discussion}

Genetic structure and bio-ecological characteristics of $P$. erythrinus populations were analyzed together for the first time in this study. The Mersin population of $P$. erythrinus showed higher degree of genetic diversity than the other populations in Turkish marine waters. At the same time, the three populations were genetically different from each other $(\mathrm{P}<0.05)$. Furthermore, the lowest $b$ value was estimated in the Iskenderun population, whereas the highest was in the Antalya population. The highest asymptotic length $\left(L_{\infty}\right)$ was determined in the Mersin population.

In the mtDNA sequencing analysis of D-loop region, nine different haplotypes were detected and the mean haplotype diversity of $P$. erythrinus was found to be 0.7485 at the present study which was lower than to the other studies by Tabata and Mizuta (1997); Ball, Beal, Chapman, and Sedberry (2007); Ashton (2013); Angiulli et al. (2016); Viret et al. (2018), whereas higher than the study by Stockley, Menezes, Pinho, and Rogers (2005). Tabata and Mizuta (1997) found haplotype diversity of
Pagrus major populations based on D-loop gene to be 0.892. Ball et al. (2007) studied population genetic analysis of Pagrus pagrus using D-loop gene and determined haplotype diversity as 0.998. Ashton (2013) conducted population genetic analysis of Pagrus auratus based on D-loop sequence and detect haplotype diversity as 0.858. Angiulli et al. (2016) carried out phylogeographical analysis of Pagellus erythrinus populations and found haplotype diversity inferred from D-loop sequence data 1.000. Viret et al. (2018) observed haplotype diversity of Dentex dentex populations as 0.985. Conversely, Stockley et al. (2005) found lower haplotype diversity of Pagellus bogaraveo populations to be 0.5919 . Hence, low haplotype diversity may be associated with the properties of the marine species (Palumbi, 1994) and the specific features of the D-loop gene as well as ecological and human-originated factors.

The mean genetic diversity among $P$. erythrinus populations was also low (0.0127) when compared to the studies on the same species using D-loop gene such as Apostolidis et al. (2009); Fassatoui, Chenui, and Romdhane (2012); whereas higher than the study by Angiulli et al. (2016). When we compare to the mean genetic diversity findings of other sea bream species on the basis of $D$-loop sequence data, we found lower than the studies by Ball et al. (2007); Ashton (2013); Viret et al. (2018), whereas higher than the studies by Jean, Lee, Chen, and Hui (1998); Stockley et al. (2005). Apostolidis et al. (2009) analyzed mitochondrial DNA sequences of $P$. erythrinus populations using D-loop gene and found mean genetic diversity as 1.12. Fassatoui et al. (2012) investigated genetic structure of $P$. erythrinus populations inferred from mtDNA sequence analysis of D-loop gene and found mean genetic diversity to be 0.483. Angiulli et al. (2016) investigated the genetic variation of $P$. erythrinus populations based on the geographical distribution and found genetic diversity value between 0.008 and 0.012 . Ball et al. (2007) found mean genetic diversity on the studied population structure of the red porgy Pagrus pagrus as 0.014 . Ashton (2013) investigated genetic structure of the silver sea bream Pagrus auratus and determined mean 


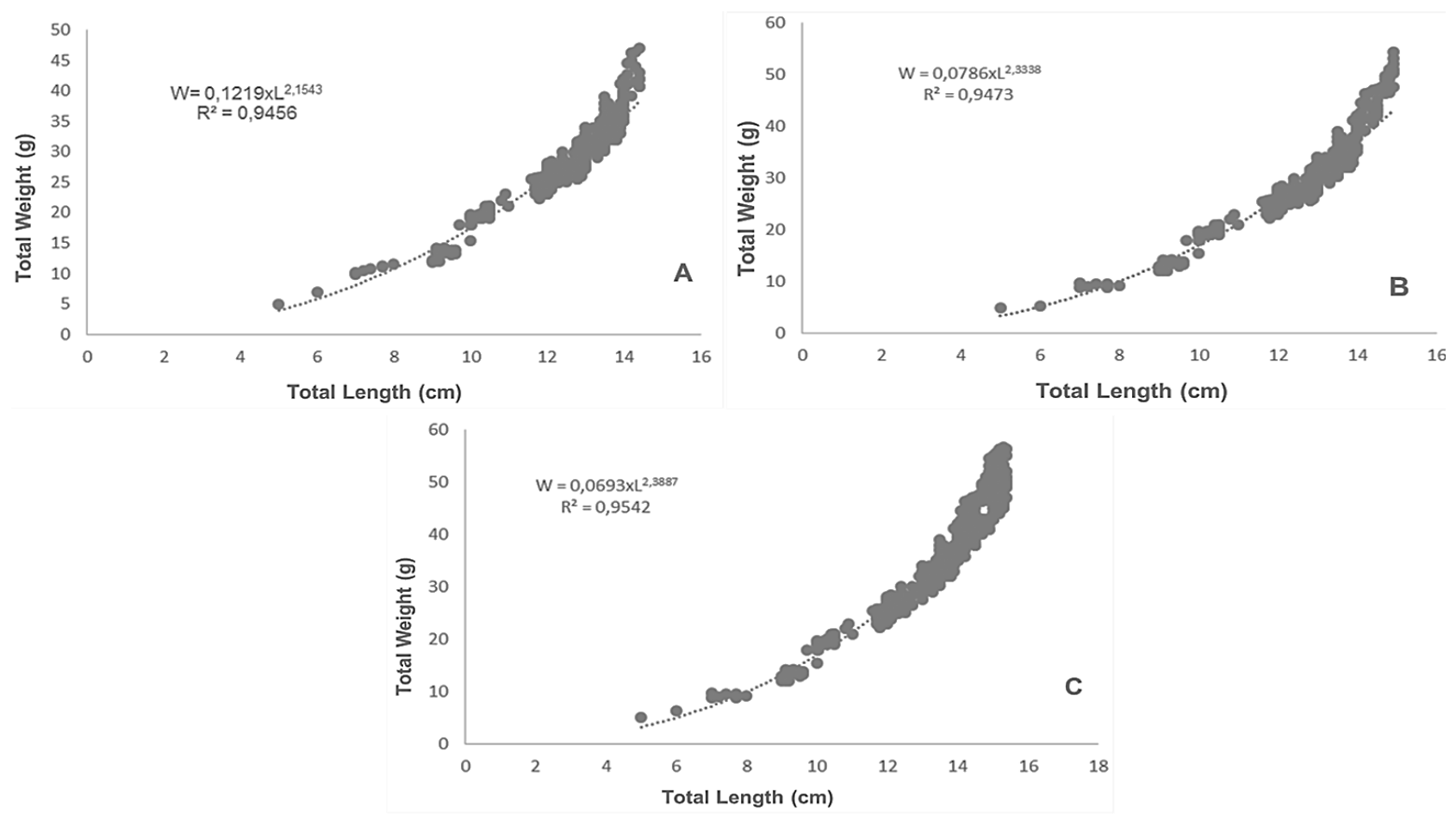

Figure 4. Length-weight relationships (A) ISK, (B) MER and (C) ANT populations of all individuals.

genetic diversity value as 0.031 . Viret et al. (2018) assessed the genetic structure and phylogeography of the common dentex Dentex dentex and found genetic diversity to be 0.02104 . On the other hand, Jean et al. (1998) studied genetic structure of the black porgy Acanthopagrus schlegeli populations and found genetic diversity 0.00275 . Stockley et al. (2005) found genetic diversity value to be 0.002111 in the blackspot seabream Pagellus bogaraveo populations. Fisheries pressure in Turkish marine waters might lead to a decrease in genetic diversity and a reduction in evolutionary potential and adaptability (Allendorf, England, Luikart, Ritchie, \& Ryman, 2008).

Intra-population genetic diversity was observed as the lowest (0.0006) in the Iskenderun Bay population. The low genetic diversity observed in the Iskenderun Bay population may relate to the potential excessive fisheries activities and other environmental factors reported by Koçak, Kubilay, Tuğrul, and Mihalopoulos (2010); Yemişken, Dalyan, and Eryılmaz (2014); Turan, Ergüden, and Gürlek (2016). Koçak et al. (2010) reported that the potential of the chemical industry units and municipal wastes could be origin of the pollution in the Iskenderun Bay. Yemişken et al. (2014) noted that regional fish stocks have been exposed to heavy fisheries activities in Iskenderun Bay and are abused every year by numereous trawler vessels. Turan et al. (2016) stated that the temperature has increased progressively in the last 40 years in the Iskenderun Bay and this situation affects biodiversity in this region. Tajima's D (Tajima, 1989) was found to be 1.363177 for $P$. erythrinus populations which indicate that the observed heterozygosity is higher than that expected. In point of biological explanation, the positive Tajima's D indicates low levels of polymorphisms, indicating an inclination or sign regarding population contraction.

The overall genetic divergence among $P$. erythrinus populations was found low (0.0183). Tabata and Mizuta (1997) investigated genetic structure of the red sea bream Pagrus major populations from four locations of Western Japanese coasts by using D-loop and found mean genetic divergence as 0.0158 . When we compare the present finding with other sea bream species $P$. major, genetic divergence is higher at $P$. erythrinus in the present study. Generally, marine species exhibit low genetic variation owing to the absence of large geographic barriers to distribution and gene flow (Avise, Reeb, \& Saunders, 1987).

In the length-weight relationships, the $b$ value in the length-weight relationship showed that negative allometric growth type was obtained from all the sampled three populations. The lowest $b$ value was observed in the Iskenderun population (2.1543). In terms of negative allometric growth, previous studies carried out in both the Mediterranean and Aegean Seas showed almost same results with (Rijavec \& Lupanovic, 1965; Andaloro \& Giarritta, 1985; Vassilipoulo et al., 1986; Livadas, 1989; Özaydın, 1997; Hoşsucu \& Çakır, 2003; Metin et al., 2011; Busalacchi et al., 2014; Özvarol, 2014; Akalın et al., 2015; Fassatoui et al., 2019; Yapıcı \& Filiz, 2019). The $b$ values in each fish population may vary based on the species, sex, age, sexual maturity of the fish as well as the season and fish feeding (Ricker, 1975).

In the age-length relationships, the asymptotic length $\left(L_{\infty}\right)$ was determined as $50.48 \mathrm{~cm}$ total length in the Mersin population. In the other coasts of Turkish marine waters, this value was found to be $35.7 \mathrm{~cm}$ by Tosunoğlu et al. (1997) in Gülbahçe Bay, Hoşsucu and Çakır (2003) reported as $23.99 \mathrm{~cm}$ in Edremit Bay, Metin 
et al. (2011) found to be $30.7 \mathrm{~cm}$, Yapıcı and Filiz (2019) calculated as $38.29 \mathrm{~cm}$ in the Gökova Bay. In different coasts of Mediterranean, Andalaro and Giarritta (1985) found to be $36.7 \mathrm{~cm}$ in Sicily, Girardin and Quignard (1985) determined as $34.5 \mathrm{~cm}$ in the Lyon Bay, Papaconstantinou et al. (1988) calculated to be $32.6 \mathrm{~cm}$ in Greek coasts, Livadas (1989) found $30 \mathrm{~cm}$ for Cyprus, Somarakis and Machias (2002) reported $27.8 \mathrm{~cm}$ on the Cretan Shelf, Busalacchi et al. (2014) estimated at 45.4 $\mathrm{cm}$ in the southern Tyrrhenian Sea, Fassatoui et al. (2019) calculated as $34.07 \mathrm{~cm}$ and $28.01 \mathrm{~cm}$ for the northern and southern Tunisian waters, respectively. These findings reveal the difference in the growth rate of $P$. erythrinus in the regions between the Western Mediterranean and Eastern Mediterranean, and also Mediterranean and Aegean coasts of Turkey. Differences in estimated asymptotic length for both sites can be attributed to phylogeographic variation of each population in such as fisheries, climate and pollutants. The detected differences may be resulting from genetic factors, environmental variables and/or their combination.

\section{Conclusion}

This study supplies first ecosystem-based fishery information about the genetic structure and biological characteristics of $P$. erythrinus populations from eastern Mediterranean coasts of Turkey. The results obtained from genetic analysis and biological parameters support each other. The detected lowest genetic diversity and $b$ value from Iskenderun population prove that preventions should be taken for fisheries management aspect in the face of this situation.

\section{Acknowledgements}

Thanks to Republic of Turkey Ministry of Food, Agriculture and Livestock General Directorate of Agricultural Research and Policies (TAGEM-16/AR$\mathrm{GE} / 21$ ) for financial support. This article was oralpresented at the International Next Generation Biometry Workshop and Course.

\section{References}

Abella, A., Colloca, F., Sartor, P., \& Mannini, A. (2010). General fisheries commission for the Mediterranean (GFCM). SAC SCSA. WG on Stock Assessment of Demersal Species. Stock Assessment Forms.

Akalın, S., İlhan, D., \& Özaydın, O. (2015). Length-Weight Relationships for 30 Demersal Fish Species from Çandarli Bay (North Aegean Sea, Turkey). Croatian Journal of Fisheries: Ribarstvo, 73(2), 73-76. https://doi.org/10.14798/73.2.822.

Allendorf, F. W., England, P. R., Luikart, G., Ritchie, P. A., \& Ryman, N. (2008). Genetic Effects of Harvest on Wild Animal Populations. Trends in Ecology \& Evolution, 23(6), 327-337.

https://doi.org/10.1016/j.tree.2008.02.008.

Andalaro, F., \& Giarritta, S. P. (1985). Contribution to the knowledge of the age and growth of striped mullet, Mullus barbatus (L. 1758) and red mullet, Mullus surmuletus (L. 1758) in the Sicilian Channel. FAO Fisheries Report, 336, 89-92.

Angiulli, E., Sola, L., Ardizzone, G., Fassatoui, C., \& Rossi, A. R. (2016). Phylogeography of the Common Pandora Pagellus erythrinus in the Central Mediterranean Sea: Sympatric Mitochondrial Lineages and Genetic Homogeneity. Marine Biology Research, 12(1), 4-15. https://doi.org/10.1080/17451000.2015.1069355.

Apostolidis, A., Moutou, K., Stamatis, C., \& Mamuris, Z. (2009). Genetic Structure of Three Marine Fishes from the Gulf of Pagasitikos (Greece) Based on Allozymes, RAPD, and mtDNA RFLP Markers. Biologia, 64(5), 1005-1010. https://doi.org/10.2478/s11756-009-0161-0.

Ashton, D. T. (2013). Population Genetics of New Zealand Pagrus auratus and Genetic Variation of an Aquaculture Broodstock (Master's Thesis). Victoria University of Wellington, New Zealand.

Avise, J. C., Reeb, C. A., \& Saunders, N. C. (1987). Geographic Population Structure and Species Differences in Mitochondrial DNA of Mouthbrooding Marine Catfishes (Ariidae) and Demersal Spawning Toadfishes (Batrachoididae). Evolution, 41(5), 991-1002. https://doi.org/10.1111/j.1558-5646.1987.tb05872.x.

Ayyıldız, H., \& Altın, A. (2018). Age and Growth Rates at the Early Life Stages of Common Pandora (Pagellus erythrinus) Based on Analysis of Otolith Microstructure. Fishery Bulletin, 116(2), 183-190. https://doi.org/10.7755/FB.116.2.7.

Ball, A. O., Beal, M. G., Chapman, R. W., \& Sedberry, G. R. (2007). Population Structure of Red Porgy, Pagrus pagrus, in the Atlantic Ocean. Marine Biology, 150(6), 1321-1332. https://doi.org/10.1007/s00227-006-0425y.

Ben Smida, M. A., \& Hadhri, N. (2014). Reproductive Cycle and Size at First Sexual Maturity of Common Pandora Pagellus erythrinus (Sparidae) from the Bay of Monastir (Tunisia, central Mediterranean). Annales, Series Historia Naturalis, 24(1), 31-40.

Brown, W. M. (1985). The Mitochondrial Genome of Animals. In R. J. Macintyre (Ed.), Molecular Evolutionary Genetics (pp. 95-130). Plenum, New York., 632 pp.

Busalacchi, B., Bottari, T., Giordano, D., Profeta, A., \& Rinelli, P. (2014). Distribution and Biological Features of the Common Pandora, Pagellus erythrinus (Linnaeus, 1758), in the Southern Tyrrhenian Sea (Central Mediterranean). Helgoland Marine Research, 68(4), 491-501. https://doi.org/10.1007/s10152-014-0404-5.

Caragitsou, E., \& Papaconstantinou, C. (1988). Feeding Habits of Red Pandora (Pagellus erythrinus) off the Western Coast of Greece. Journal of Applied Ichthyology, 4(1), 1422.

https://doi.org/10.1111/j.1439-0426.1988.tb00543.x.

Coelho, R., Bentes, L., Correia, C., Gonçalves, J., Lino, P. G., Monteiro, P., \& Erzini, K. (2010). Life History of the Common Pandora, Pagellus erythrinus (Linnaeus, 1758) (Actinopterygii: Sparidae) from Southern Portugal. Brazilian Journal of Oceanography, 58(3), 233-245. https://doi.org/10.1590/s1679-87592010000300006.

Erzini, K., Gonçalves, J. M., Bentes, L., Lino, P. G., \& Ribeiro, J. (1998). Species and Size Selectivity in a 'Red'sea Bream Longline 'metier'in the Algarve (southern Portugal). Aquatic Living Resources, 11(1), 1-11. https://doi.org/10.1016/S0990-7440(99)80025-4.

European Commission, (2006). Council Regulation (EC) No 
1967/2006 of 21 December 2006 concerning management measures for the sustainable exploitation of fishery resources in the Mediterranean Sea, amending Regulation (EEC) No 2847/93 and repealing Regulation (EC) No 1626/94. Official Journal L 409, 30/12/2006, pp. 9-86.

FAO, 2018. FishStat plus. Capture production 1950-2012, Aquaculture production 1950-2016. Retrieved from http://www.fao.org/fishery/statistics/software/fishstatj /en.

Fassatoui, C., \& Romdhane, M. S. (2010). Variabilité Génétique Entre Les Classes D'âge Chez Le Pageot Commun (Pagellus erythrinus, Sparidae) Des Côtes Nord Tunisiennes. Bulletin de I'Institut National des Sciences et Technologies de la Mer de Salammbô, 37 (2010), 1-12.

Fassatoui, C., Mdelgi, E., \& Romdhane, M. (2009). A Preliminary Investigation of Allozyme Genetic Variation and Population Structure in Common Pandora (Pagellus erythrinus, Sparidae) from Tunisian and Libyan Coasts. Ichthyological Research, 56, 301-07. https://doi.org/10.1007/s10228-008-0094-6

Fassatoui, C., Mdelgi, E., \& Romdhane, M. (2011). Short-Term Temporal Genetic Investigation of Two Populations of Pagellus erythrinus (Linnaeus, 1758, Sparidae) from Western and Eastern Mediterranean Basins off the Tunisian coast. Marine Biology Research, 7, 147-158. https://doi.org/10.1080/17451001003762792.

Fassatoui, C., Chenui, A., \& Romdhane, M. S. (2012). Relationships between Heterozygosity, Growth Parameters and Age in the Common Pandora Pagellus erythrinus (Sparidae) in the Gabes Gulf (Tunisia). Marine Ecology Progress Series, 445, 251-261. ttps://doi.org/10.3354/meps09531.

Fassatoui, C., Hmida, L., Jenhani, A. B. R., \& Romdhane, M. S. (2019). Length-weight relationship and growth parameters of the commercial fish Pagellus erythrinus (Linnaeus, 1758) (Actinopterygii: Sparidae) from northern and southern Tunisia. Biological Letters, 54(1), 3-11. https://doi.org/10.2478/biolet-2019-0001.

Froese, R., \& Pauly, D. (2019). FishBase. World Wide Web electronic publication. Retrieved from www.fishbase.org.

Girardin, M., \& Quignard, J. P. (1985). Croissance de Pagellus erythrinus (Pisces: Teleostéen, Sparidae) dans le Golfe du Lion. Cybium, 9(4), 359-374.

Gökçe, G., Aydın, i.., \& Metin, C. (2007). Length-weight relationships of 7 fish species from the North Aegean Sea, Turkey. International Journal of Natural and Engineering Sciences, 1, 51-52.

Gökçe, G., Çekic, M., \& Filiz, H. (2010). Length-Weight Relationships of Marine Fishes off Yumurtalık Coast (Iskenderun Bay), Turkey. Turkish Journal of Zoology, 34(1), 101-104. https://doi.org/10.3906/zoo-0905-33.

Gurbet, R., Akyol, O., \& Yalçın, E. (2012) Catch Per Unit Effort and Mortality Rates of Two Sparid Species, Pagellus acarne and Pagellus erythrinus from Bottom Trawl Fishery in Izmir Bay, Aegean Sea. Journal of Animal Veterinary Advances, 11, 681-686. https://doi.org/10.3923/javaa.2012.681.686.

Hall, T.A. (1999). BioEdit: A User-Friendly Biological Sequence Alignment Editor and Analysis Program for Windows 95/98/NT. Nucleic Acids Symposium Series, 41, 95-98.

Harrison, R. G. (1989). Animal mitochondrial DNA as a genetic marker in population and evolutionary biology. Trends in Ecology \& Evolution, 4(1), 6-11. https://doi.org/10.1016/0169-5347(89)90006-2.
Hashem, M. T., \& Gassim, A. S. (1981). Some Aspects of the Fishery Biology of Pagellus erythrinus (L) in the Libyan waters. Bulletin of the Institute of Oceanography and Fisheries ARE, 7(3), 429-441.

Holden, M. J., \& Raitt, D. F. S. (1974). Manual of Fisheries Science. Part 2-Methods of Resource Investigation and Their Application. Documents Techniques FAO sur les Peches (FAO)-Documentos Tecnicos de la FAO sobre la Pesca (FAO).

Hoşsucu, B., \& Çakır, D. T. (2003). Some Parameters about Population Biology of the Common Pandora (Pagellus erythrinus L., 1758) (Sparidae) in the Edremit Bay (Turkey). E.U. Journal of Fisheries \& Aquatic Sciences, 20(3-4), 329-336.

IGFA. (2001). Database of IGFA angling records until 2001.

Jean, C. T., Lee, S. C., Chen, C. T., \& Hui, C. F. (1998). Variation in mitochondrial DNA sequences of black porgy, Acanthopagrus schlegeli, in the coastal waters of Taiwan. Zoological Studies Taipei, 37, 22-30.

Jukes, T. H., Cantor, C. R. (1969). Evolution of protein molecules. In: Munro, H. N. (Ed.), Mammalian Protein Metabolism III (pp. 21-132). Academic Press, New York.

Koçak, M., Kubilay, N., Tuğrul, S., Mihalopoulos, N., (2010). Atmospheric Nutrient Inputs to the Northern Levantine Basin from A Long-Term Observation: Sources and Comparison with Riverine Inputs. Biogeosciences 7, 4037-4050. https://doi.org/10.5194/bg-7-4037-2010.

Livadas, R. J. (1989). A Study of the Biology and Population Dynamics of Pandora (Pagellus erythrinus L., 1758), family Sparidae, in the Seas of Cyprus. FAO Fisheries Report, 412, 58-76.

Mahdi, H., Talet, L. B., \& Boutiba, Z. (2018). Reproductive Biology of the Common Pandora Pagellus erythrinus (Linnaeus, 1758) of Oran Bay (Algerian west coasts). Turkish Journal of Fisheries and Aquatic Sciences, 18(1), 1-7. https://doi.org/10.4194/1303-2712-v18_1_01.

Metin, G., ilkyaz, A. T., Soykan, O., \& Kınacıgil, H. T. (2011). Biological Characteristics of the Common Pandora, Pagellus erythrinus (Linnaeus, 1758), in the Central Aegean Sea. Turkish Journal of Zoology, 35, 307-315. https://doi.org/10.3906/zoo-0904-4.

Micale, V., Garaffo, M., Genovese, L., Spedicato, M. T., \& Muglia, U. (2006). The Ontogeny of the Alimentary Tract during Larval Development in Common Pandora Pagellus erythrinus L. Aquaculture, 251(2-4), 354-365.

Nei, M., 1987. Molecular Evolutionary Genetics. Columbia University Press., 512 pp.

Özaydın, O. (1997). Ege Denizi'nde Yaşayan Bazı Sparid (Pisces, Sparidae) Türlerinin Biyolojisi ve Beslenme Rejimi Üzerine Araştırmalar (Doktora tezi). Dokuz Eylül Üniversitesi, İmir, Türkiye (In Turkish).

Öztekin, A., Özekinci, U., \& Daban, I. B. (2016). Length-Weight Relationships of 26 Fish Species Caught by Longline from the Gallipoli Peninsula, Turkey (northern Aegean Sea). Cahiers de Biologie Marine, 57, 335-342.

Özvarol, Y. (2014). Length-Weight Relationships of 14 Fish Species from the Gulf of Antalya (northeastern Mediterranean Sea, Turkey). Turkish Journal of Zoology, 38(3), 342-346. https://doi.org/10.3906/zoo-1308-44.

Palsbøll, P. J., Berube, M., \& Allendorf, F. W. (2007). Identification of management Units Using Population Genetic Data. Trends in Ecology \& Evolution, 22(1), 1116. https://doi.org/10.1016/j.tree.2006.09.003.

Palumbi, S. R. (1994). Genetic Divergence, Reproductive Isolation, and Marine Speciation. Annual Review of Ecology and Systematics, 25(1), 547-572. 
https://doi.org/10.1146/annurev.es.25.110194.002555.

Papaconstantinou, C., Mytilineou, C., \& Panos, T. (1988). Aspects of the Life History and Fishery of Red Pandora, Pagellus erythrinus (Sparidae) off Western Greece. Cybium, 12(4), 267-280.

Posada, D., \& Crandall, K.A. (1998). ModelTest: Testing the Model of DNA Substitution. Bioinformatics 14, 817-818. https://doi.org/10.1093/bioinformatics/14.9.817.

Ricker, W. E. (1973). Linear Regressions in Fishery Research. Journal of the Fisheries Research Board of Canada, 30, 409-434. https://doi.org/10.1139/f73-072.

Ricker, W.E. (1975). Computation and Interpretation of Biological Statistics of Fish Populations. Fisheries Research Board of Canada Bulletin, 191, 1-382.

Rijavec, L., \& Lupanovic, S. (1965). A Contribution to the Knowledge of Biology of Pagellus erythrinus L. in the Middle Adriatic. Rapp. PV Réun. CIESM, 18, 195-200.

Rossi, A. R., Colangelo, P., Berline, L., Angiulli, E., Ardizzone, G., Fassatoui, C., \& Sola, L. (2019). Influence of Hydrodynamic Connectivity on the Genetic Structure and Gene Flow of the Common Pandora Pagellus erythrinus. Hydrobiologia, 834(1), 103-117. https://doi.org/10.1007/s10750-019-3914-y.

Russell, B. (2014). Pagellus erythrinus. The IUCN Red List of Threatened Species 2014: e.T170224A1296530.

Saitou, N., \& Nei, M. (1987). The Neighbor-Joining Method: A New Method for Reconstructing Phylogenetic Trees. Molecular Biology and Evolution, 4(4), 406-425. https://doi.org/10.1093/oxfordjournals.molbev.a040454.

Sambrook, J., Fritsch, E.F., \& Maniatis, T. (1989). Molecular Cloning: A Laboratory Manual Second Edition. New York Cold, USA, Spring Harbor Press., 1659 pp.

Sangün, L., Akamca, E., \& Akar, M. (2007). Weight-length Relationships for 39 Fish Species from the North-Eastern Mediterranean Coast of Turkey. Turkish Journal of Fisheries and Aquatic Sciences, 7(1), 37-40.

Šantić, M., Paladin, A., \& Rađa, B. (2011). Feeding Habits of Common Pandora Pagellus erythrinus (Sparidae) from Eastern Central Adriatic Sea. Cybium, 35(2), 83-90.

Santos, M. N., Monteiro, C. C., \& Erzini, K. (1995). Aspects of the Biology and Gillnet Selectivity of the Axillary Seabream (Pagellus acarne, Risso) and Common Pandora (Pagellus erythrinus, Linnaeus) from the Algarve (south Portugal). Fisheries Research, 23(3-4), 223-236. https://doi.org/10.1016/0165-7836(94)00354-Y.

Somarakis, S., \& Machias, A. (2002). Age, Growth and Bathymetric Distribution of Red Pandora (Pagellus erythrinus) on the Cretan shelf (eastern Mediterranean). Journal of the Marine Biological Association of the United Kingdom, 82(1), 149-160. https://doi.org/10.1017/S002531540200526X.

Sparre, P., \& Venema, S. C. (1998). Introduction to Fish Stock Assessment. Part 1: Manual. FAO Fisheries Technical Paper, 306(1).

Spedicato, M. T., Greco, S., Sophronidis, K., Lembo, G., Giordano, D., \& Argyri, A. (2002). Geographical Distribution, Abundance and Some Population Characteristics of the Species of the Genus Pagellus (Osteichthyes: Percirformes) in different areas of the Mediterranean. Scientia Marina, 66(S2), 65-82. https://doi.org/10.3989/scimar.2002.66s265.

Stergiou, K. I., \& Moutopoulos, D. K. (2001). A Review of Length-Weight Relationships of Fishes from Greek Marine Waters. Fishbyte, 24, 23-39.

Stockley, B., Menezes, G., Pinho, M. R., \& Rogers, A. D. (2005).
Genetic population Structure in the Black-Spot Sea Bream (Pagellus bogaraveo Brünnich, 1768) from the NE Atlantic. Marine Biology, 146(4), 793-804. https://doi.org/10.1007/s00227-004-1479-3.

Tabata, K., \& Mizuta, A. (1997). RFLP Analysis of the mtDNA Dloop Region in Red Sea Bream Pagrus major Population from Four Locations of Western Japan. Fisheries Science, 63(2), 211-217. https://doi.org/10.2331/fishsci.63.211.

Tajima, F. (1989). Statistical method for testing the neutral mutation hypothesis by DNA polymorphism. Genetics 123, 585-595.

Tamura, K., Peterson, D., Peterson, N., Stecher, G., Nei, M., \& Kumar, S. (2011). MEGA5: Molecular Evolutionary Genetics Analysis Using Maximum Likelihood, Evolutionary Distance, and Maximum Parsimony Methods. Molecular Biology and Evolution, 28, 27312739. https://doi.org/10.1093/molbev/msr121.

Thompson, J. D., Higgins, D. G., \& Gibson, T. J. (1994). CLUSTAL W: Improving the Sensitivity of Progressive Multiple Sequence Alignment through Sequence Weighting, Position-Specific Gap Penalties and Weight Matrix Choice. Nucleic Acids Research, 22, 4673-4680. https://doi.org/10.1093/nar/22.22.4673.

Tosunoğlu, Z., Akyol, O., Metin, G., Tokaç, A., \& Ünsal, S. (1997). The study on the population characteristics of three sparid species in the Gülbahçe Bay. E.U. Journal of Fisheries \& Aquatic Sciences, 14, 127-143.

Turan, C., Ergüden, D., \& Gürlek, M. (2016). Climate Change and Biodiversity Effects in Turkish Seas. Natural and Engineering Sciences, 1, 15-24. https://doi.org/10.28978/nesciences.286240.

TURKSTAT. (2016). Fishery Statistics. Ankara: Turkish Statistical Institute.

Valdes, P., García-Alcázar, A., Abdel, I., Arizcun, M., Suárez, C., \& Abellán, E. (2004). Seasonal Changes on Gonadosomatic Index and Maturation Stages in Common Pandora Pagellus erythrinus (L.). Aquaculture International, 12(4-5), 333-343.

https://doi.org/10.1023/B:AQUI.0000042136.91952.9e.

Viret, A., Tsaparis, D., Tsigenopoulos, C. S., Berrebi, P., Sabatini, A., Arculeo, M., Fassatoui, C., Magoulas, A., Marengo, M., Morales-Nin, B., Caill-Milly, N., \& Durieux, E. D. H. (2018). Absence of Spatial Genetic Structure in Common Dentex (Dentex dentex Linnaeus, 1758) in the Mediterranean Sea as Evidenced by Nuclear and Mitochondrial Molecular Markers. PLoS One, 13(9), e0203866.

https://doi.org/10.1371/journal.pone.0203866.

Whitehead, P. J. P., Bauchot, M. L., Hureau, J. C., Nielsen J., \& Tortonese, E. (1986). Fishes of the North-eastern Atlantic and the Mediterranean. Journal of the Marine Biological Association of the United Kingdom, 68(01), 1013-1473. https://doi.org10.1017/s0025315400050360.

Yapıcı, S., \& Filiz, H. (2019). Biological Aspects of Two Coexisting Native and Non-Native Fish Species in the Aegean Sea: Pagellus erythrinus vs. Nemipterus randalli. Mediterranean Marine Science, 20(3), 594-602. https://doi.org/10.12681/mms.19658.

Yemişken, E., Dalyan, C., \& Eryılmaz, L. (2014). Catch and Discard Fish Species of Trawl Fisheries in the Iskenderun Bay (North-eastern Mediterranean) with Emphasis on Lessepsian and Chondricthyan Species. Mediterranean Marine Science, 15, 380-389. https://doi.org/10.12681/mms.538. 